\title{
【研究ノート】
}

\section{地盤変形を考慮に入れた鋼管橋脚の地震応答の統計解析

\author{
STATISTICAL ANALYSIS OF EARTHQUAKE RESPONSE OF \\ STEEL-PIPE BRIDGE PIER WITH CONSIDERATION OF \\ UPPER LAYER DEFORMATION
}

\section{1. まえがき}

著者らは前論文1)において，比較的硬い地盤で得られ た地震記録を下層基盤での入力波として用い，上層軟弱 地盤の変形を考えた場合の鋼管橋脚の地震応答を計算し た。その際，鋼管橋脚と上層地盤をそれぞれ多質点系に 置換し, modal analysis の手法を用いて, 一つの入力地 震波に対して刻々の橋脚天端の変位を数值積分によって 求めた。したがって, この解析法では, いろいろの入力 地震波に対する橋脚の地震応答を推定しょうとする場合 には個々の入力地震波に対していちいち同じような計算 をくり返す必要があり，計算時間も長くかかる。本論は スペクトル解析の手法を用いて，地盤の変形を考慮に入 れた場合の橋脚の地震応答を統計的に計算し，比較的容 易に橋脚の地震応答の最大值が推定できる計算図表を作 製して鎆管橋脚の耐震設計の一資料を提供しようとする ものである。

\section{2. 解析の基本的な考え方}

田治見 ${ }^{2}$ は地震動およびそれに対する構造物の応答を エルゴード性をもつ定常確率過程とみなし，それらの分 散の平方根がそれぞれの最大值に比例すると考え, 構造 物の地震応答を統計的に算出する方法を提案した。本論 は地盤の变形を考慮に入れた場合の鋼管橋脚の地震応答 もやはり，エルゴード性をもつ定常確率過程であるとみ なし，地盤変形を考慮する場合の鋼管橋脚の応答の最大 值と地盤変形を考慮しない場合のそれとの比が，それぞ れの場合の応答の分散の平方根に比例するものと考え， 地盤変形を考慮する場合の鋼管橋脚の地震応答の最大値 を統計的に算出しようとするものである。

いま， $y_{\max }, \sigma^{2}$ をそれぞれ地盤の変形を考慮する場合 の橋脚天端の地震動による最大応答変位およびその分散 とし，地盤の変形を考慮しない場合には肩に添字 0 をつ けて表わし(以後これにしたがう)，つぎの式が成り立つ ものと考える。

\footnotetext{
* 正会員 工博 九州大学助教授 工学部土木工学教室

** 正会員杂州工業大学講師 開発土木工学教室
}

小 坪 清 真*・高 西 照 彦**

By Seima Kotsubo and Teruhiko Takanishi

$$
y_{\max } / y_{\max }^{0}=\sigma / \sigma^{0}=\lambda
$$

ここに，入は地盤の変形を考慮する場合と考慮しない 場合の橋脚の地震応答変位の分散の比の平方根である。

$\lambda$ が求められれば $y_{\text {max }}^{0}$ が既知の場合には，式 (1) から $y_{\text {max }}=\lambda \cdot y_{\text {max }}^{0}$ によって $y_{\text {max }}$ が推定できる。 $y_{\text {max }}^{0}$ の值は, たとえば G.W. Housner の平均速度スペ クトル ${ }^{3)}$, 田治見の加速度伝達率 ${ }^{2}$ 等からその值を推定す ることができる。

\section{3. 応答計算理論}

\section{（1）鋼管橋脚の振動モデル}

前論に押ける地震応答計算結果と本論による統計的計 算結果とを比較検討することを考虑して, 解析には前論 と全く同一の鋼管橋脚を用いた。すなわち，図一1 (a) に示すような鋼管橋脚を図一1 (b) に示すような多質点 系に置換して計算を行なった。

\section{図-1＼cjkstart鋼管橋脚とその振動モデル}

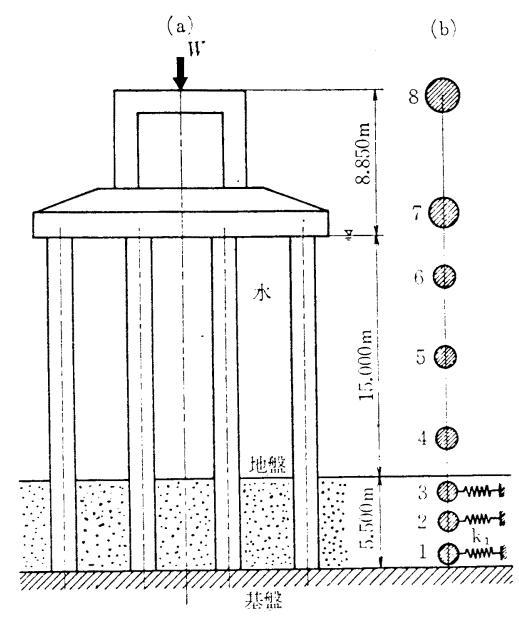

\section{（2）地盤の変位応答}

地震加速度 $\ddot{\phi}(t)$ が与えられた場合の橋脚の応答を求 めるには，まず 芩による地盤の動きを求めなければな らない。しかし，地震時に扮ける地盤の運動を解析する には厳密には波動論によらなければならないが，これは きわめて困難な問題である。したがって本論では，地盤 
のせん断弾性係数 $G$ は深さのみの関数であると仮定し, また地盤変形を次節で述べる橋脚の振動方程式に導入す る便宣上，基礎地盤を集中質点系に置換し modal analysis によってその運動を求めることにした。

地盤が下層基盤から不規則な地震加速度 $\ddot{8}$ を受けた 場合, 地盤中の $i$ 点の変位 $u_{i}$ は地盤の第 $p$ 次の振動 型を $U_{p i}$ とすれば次式のように表わせる。

$$
u_{i}=\sum_{p=1}^{P} b_{p} U_{p i}
$$

ここに, $P$ は採用する土の振動型の最高次数, $b_{p}$ は 第 $p$ 次の振動型の大きさを表わすものでつぎの微分方 程式から求められる。

$$
\begin{aligned}
& \ddot{b}_{p}+2 h_{g p} n_{g p} \dot{b}_{p}+n_{g p}{ }^{2} b_{p}=-\delta_{p} \ddot{\phi} \cdots \\
& \hat{o}_{p}=\left(\sum_{i=1}^{q} \frac{w_{i}}{g} U_{p i}\right) /\left(\sum_{i=1}^{q} \frac{w_{i}}{g} U_{p i}{ }^{2}\right)
\end{aligned}
$$

ここに, $n_{g p}, h_{g p}$ はそれぞれ地盤の第 $p$ 次の振動の 固有円振動数, 減衰定数, $q$ は地盤中の質点の数, $w_{i}$ は質点 $i$ の重量, $g$ は重力の加速度である。 $w_{i}$ は基礎 地盤を深さ方向に $\Delta l$ に等分した場合, 単位幅および単 位奥行の土を考えて $w_{i}=\rho_{s} \cdot \Delta l$ で与えられる。 $\rho_{s}$ は土 の単位体積重量。

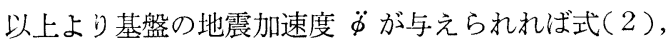
(3) から刻々における $u_{i}$ を計算することができる。

\section{（3）橋脚の変位応答の理論}

橋脚の第 $r$ 次の振動型を $Y_{r i}$ とすれば, 橋脚の $i$ 点 の変位はつぎのように書ける。

$$
y_{i}=\sum_{r=1}^{R} a_{r} Y_{r i}
$$

ここに, $R$ は採用した振動型の最高次数, $a_{r}$ は第 $r$ 次の振動型の大きさを表わすものでつぎの微分方程式か ら求めることができる。

$$
\begin{array}{r}
\ddot{a}_{r}+2 h_{s r} n_{s r} \dot{a}_{r}+n_{s r}{ }^{2} a_{r}=-\xi_{r} \ddot{\phi}+\sum_{p=1}^{P} r_{r p} n_{g p} n_{g r} b_{p} \\
\cdots \cdots \cdots \cdots \cdots(6) \cdots \cdots \cdots(6) \\
\xi_{r}=\left(\sum_{i=1}^{m} \frac{W_{i}}{g} Y_{r i}\right) /\left(\sum_{i=1}^{m} \frac{W_{i}}{g} Y_{r i}{ }^{2}\right) \cdots \cdots \cdots(7) \\
r_{r p}=\left(\sum_{i=1}^{q} K_{i} Y_{r i} U_{p i}\right) /\left(n_{g r} n_{g p} \sum_{i=1}^{m} \frac{W_{i}}{g} Y_{r i}{ }^{2}\right)
\end{array}
$$

上式で, $m$ は橋脚天端の質点番号, $n_{s r}, h_{s r}$ はそれぞ れ橋脚の第 $r$ 次の振動の固有円振動数, 減衰定数, $W_{i}$ は土と水の付着質量を考慮に入れた場合の橋脚の質点 $i$ の重量, $K_{i}$ は $i$ 点の地盤のばね定数で $K_{i}=k D N C \Delta l$ である。

ここに, $k$ 汢地盤反力係数, $D$ は鋼管外径, $N$ は鋼 管数, $C$ は群杭効果を示す係数である。

いま，橋脚の天端 $m$ 点において振動型 $Y_{r m}$ を 1 に とれば天端の変位 $y_{m}$ は式 $(5)$ からつぎのように表わ
せる。

$$
y_{m}=\sum_{r=1}^{R} a_{r}
$$

以上の結果から，橋脚と地盤の減衰定数 $h_{s r}, h_{g p}$ が 与えられれば, 地震応答計算に必要な諸定数を用いて, 橋脚天端の変位 $y_{m}$ は式 (3), (6), (9) の各式から に応じて刻々計算することができる。

\section{4. 統計的解析}

式 (2),(9) でそれぞれ $P=2, R=2$ とした場合, すなわち, 地盤と橋脚の振動次数をそれぞれ第 2 次まで とった場合に式（1）の入の值を求める計算式につい て述べる。

式 (3) および式 (6) より $b_{p}, a_{r}$ のフーリエ変換 $B_{p}(i \omega), A_{r}(i \omega)$ を求め, これを用いて変位 $y$ の分散 $\sigma^{2}$ を求めると次式で表わされる。

$$
\sigma^{2}=\lim _{T \rightarrow \infty} \int_{0}^{\infty} \frac{2 \pi}{T}\left|\sum_{r=1}^{R} A_{r}(i \omega)\right|^{2} d \omega
$$

ここに,

$$
\begin{gathered}
A_{r}(i \omega)=\frac{-\xi_{r} F(i \omega)+\sum_{p=1}^{P} \gamma_{r p} n_{g p} n_{g r} B_{p}(i \omega)}{n_{s r}{ }^{2}-\omega^{2}+2 h_{s r} n_{s r}(i \omega)} \\
\cdots \cdots \cdots \cdots \cdots(11) \\
B_{p}(i \omega)=\frac{-\delta_{p} F(i \omega)}{n_{g p}{ }^{2}-\omega^{2}+2 h_{g p} n_{g p}(i \omega)} \cdots \cdots(12)
\end{gathered}
$$

また, $F(i \omega)$ は $\ddot{\phi}(t)$ のフーリエ変換である。

$\sigma^{2}$ を式 (1) に代入し積分を遂行し， $\lambda^{2}$ の式の形を 簡単にすると結局次式のように表わすことができる。

$$
\lambda^{2}=\frac{\lambda_{11}{ }^{2}+2 \eta R_{0}{ }^{12} \lambda_{12}{ }^{2}+\eta^{2} R_{0}{ }^{22} \lambda_{22}{ }^{2}}{1+2 \eta R_{0}{ }^{12}+\eta^{2} R_{0}{ }^{22}}
$$

ここに,

$$
\begin{aligned}
& \eta=\left(\frac{\xi_{2}}{\xi_{1}}\right) /\left(\frac{n_{s 2}}{n_{s 1}}\right)^{2} \ldots \ldots \ldots \ldots \ldots \ldots \ldots \ldots \ldots \ldots \ldots . . . \\
& \lambda_{11}{ }^{2}=\sum_{k=0}^{2} \sum_{j=0}^{2} \alpha_{1 k} \alpha_{1 j} R_{k j}{ }^{11}, \\
& \lambda_{12}{ }^{2}=\sum_{k=0}^{2} \sum_{j=0}^{2} \alpha_{1 k} \alpha_{2 j} R_{k j}{ }^{12}, \\
& \lambda_{22}{ }^{2}=\sum_{k=0}^{2} \sum_{j=0}^{2} \alpha_{2 k} \alpha_{2 j} R_{k j}{ }^{22} \\
& R_{0}{ }^{12}=I_{00}{ }^{12} / I_{00}{ }^{11}, \quad R_{0}{ }^{22}=I_{00}{ }^{22} / I_{00}{ }^{11} \ldots \ldots . .
\end{aligned}
$$

式（15）において,

$$
\left.\begin{array}{l}
\alpha_{10}=1, \quad \alpha_{11}=\frac{r_{11} \delta_{1}}{\xi_{1}}, \quad \alpha_{12}=\left(\frac{r_{12} \delta_{2}}{\xi_{1}}\right) /\left(\frac{n_{g 2}}{n_{g 1}}\right) \\
\alpha_{20}=1, \quad \alpha_{21}=\left(\frac{r_{21} \delta_{1}}{\xi_{2}}\right)\left(\frac{n_{g 2}}{n_{g 1}}\right), \quad \alpha_{22}=\frac{r_{22} \hat{o}_{2}}{\xi_{2}}
\end{array}\right\}
$$

$$
\begin{aligned}
& R_{k j^{11}}=I_{k j^{11}} / I_{00}{ }^{11}, \quad R_{k j^{12}}=I_{k j^{12}} / I_{00}{ }^{12}, \\
& R_{k j^{22}}=I_{k j^{22}} / I_{00}{ }^{22} \\
& R_{j k}{ }^{11}=R_{k j}{ }^{11}, \quad R_{j k}{ }^{22}=R_{k j}{ }^{22},
\end{aligned}
$$

式 (16)，(18)の $I$ はつぎに示すような分積值を表わ す。 


$$
\begin{aligned}
& I_{00}{ }^{11}=\int_{0}^{\infty} \frac{\Phi(\omega)}{S_{1}(\omega)} d \omega \\
& I_{01}{ }^{11}=\int_{0}^{\infty}\left(1-\frac{\omega^{2}}{n_{g 1}{ }^{2}}\right) \frac{\Phi(\omega)}{N_{1}(\omega) S_{1}(\omega)} d \omega \\
& I_{02}{ }^{11}=\int_{0}^{\infty}\left(1-\frac{\omega^{2}}{n_{g 2}{ }^{2}}\right) \frac{\Phi(\omega)}{N_{2}(\omega) S_{1}(\omega)} d \omega \\
& I_{11}{ }^{11}=\int_{0}^{\infty} \frac{\Phi(\omega)}{N_{1}(\omega) S_{1}(\omega)} d \omega \\
& I_{12}{ }^{11}=\int_{0}^{\infty} \frac{N_{3}(\omega) \Phi(\omega)}{N_{1}(\omega) N_{2}(\omega) S_{1}(\omega)} d \omega \\
& I_{22}{ }^{11}=\int_{0}^{\infty} \frac{\Phi(\omega)}{N_{2}(\omega) S_{1}(\omega)} d \omega
\end{aligned}
$$

$$
\begin{aligned}
& I_{00}{ }^{12}=\int_{0}^{\infty} \frac{S_{3}(\omega) \Phi(\omega)}{S_{1}(\omega) S_{2}(\omega)} d \omega, \quad I_{01}{ }^{12}=I_{a}-4 h_{g 1} I_{d} \\
& I_{02}{ }^{12}=I_{b}-4 h_{g 2} I_{e}, \quad I_{10}{ }^{12}=I_{a}+4 h_{g 1} I_{d} \\
& I_{11}{ }^{12}=\int_{0}^{\infty} \frac{S_{3}(\omega) \Phi(\omega)}{N_{1}(\omega) S_{1}(\omega) S_{2}(\omega)} \cdot d \omega, \\
& I_{12}{ }^{12}=I_{c}-4 I_{f} \\
& I_{20}{ }^{12}=I_{b}+4 h_{g 2} I_{e}, \quad I_{21}{ }^{12}=I_{c}+4 I_{f} \\
& I_{22}{ }^{12}=\int_{0}^{\infty} \frac{S_{3}(\omega) \Phi(\omega)}{N_{2}(\omega) S_{1}(\omega) S_{2}(\omega)} d \omega \\
& I_{a}=\int_{0}^{\infty}\left(1-\frac{\omega^{2}}{n_{g 1}{ }^{2}}\right) \frac{S_{3}(\omega) \Phi(\omega)}{N_{1}(\omega) S_{1}(\omega) S_{2}(\omega)} d \omega, \\
& I_{b}=\int_{0}^{\infty}\left(1-\frac{\omega^{2}}{n_{g 2}{ }^{2}}\right) \frac{S_{3}(\omega) \Phi(\omega)}{N_{2}(\omega) S_{1}(\omega) S_{2}(\omega)} d \omega \\
& I_{c}=\int_{0}^{\infty} \frac{N_{3}(\omega) S_{3}(\omega) \Phi(\omega)}{N_{1}(\omega) N_{2}(\omega) S_{1}(\omega) S_{2}(\omega)} d \omega, \\
& I_{d}=\int_{0}^{\infty} \frac{\omega^{2}}{n_{g 1} n_{s 2}} \frac{S_{4}(\omega) \Phi(\omega)}{N_{1}(\omega) S_{1}(\omega) S_{2}(\omega)} d \omega \\
& I_{e}=\int_{0}^{\infty} \frac{\omega^{2}}{n_{g 2} n_{s 2}} \frac{S_{4}(\omega) \Phi(\omega)}{N_{2}(\omega) S_{1}(\omega) S_{2}(\omega)} d \omega, \\
& I_{f}=\int_{0}^{\infty} \frac{\omega^{2}}{n_{g 2} n_{s 2}} \frac{N_{4}(\omega) S_{4}(\omega) \Phi(\omega)}{N_{1}(\omega) N_{2}(\omega) S_{1}(\omega) S_{2}(\omega)} d \omega
\end{aligned}
$$

$I_{k j}{ }^{22}$ は式 (19) において $S_{1}(\omega)$ の代りに $S_{2}(\omega)$ と すればよい。また，式 (19)，(20) において，

$$
\begin{aligned}
& N_{1}(\omega)=\left(1-\frac{\omega^{2}}{n_{g_{1}}{ }^{2}}\right)^{2}+4 h_{g_{1}}{ }^{2} \frac{\omega^{2}}{n_{g_{1}}{ }^{2}} \\
& N_{2}(\omega)=\left(1-\frac{\omega^{2}}{n_{g_{2}}{ }^{2}}\right)^{2}+4 h_{g_{2}}{ }^{2} \frac{\omega^{2}}{n_{g^{2}}{ }^{2}} \\
& N_{3}(\omega)=\left(1-\frac{\omega^{2}}{n_{g_{1}}{ }^{2}}\right)\left(1-\frac{\omega^{2}}{n_{g_{2}}{ }^{2}}\right)+4 h_{g_{1}} h_{g_{2}} \frac{\omega^{2}}{n_{g_{1}} n_{g_{2}}} \\
& N_{4}(\omega)=\left(1-\frac{\omega^{2}}{n_{g_{1}}{ }^{2}}\right) h_{g_{2}}-\frac{n_{g_{2}}}{n_{g_{1}}}\left(1-\frac{\omega^{2}}{n_{g_{2}}{ }^{2}}\right) h_{g_{1}}
\end{aligned}
$$

$S_{1}(\omega) \sim S_{4}(\omega)$ は上式で添字 $g$ を添字 $s$ に書き直せ ばよい。

また, $\Phi(\omega)$ は地震加速度 $\ddot{\phi}(t)$ のパワー スペクトル を示し, $\dddot{\phi}(t)$ のフーリエ変換を $F(i \omega)$ とすれば $\Phi(\omega)$ は次式のように表わされる。

$$
\Phi(\omega)=\lim _{T \rightarrow \infty} \frac{2 \pi}{T}|F(i \omega)|^{2}
$$

以上, $\lambda$ の計算式について述べたが, 実際問題として $\lambda$ を求めるのに個々の場合に式 (19)，(20）の積分值を 計算するのはきわめて繁雑であり実用的でない。そこで あらかじめ地盤と橋脚の固有振動数, 減衰定数等 $\left(n_{g}\right.$, $h_{g}, n_{s}, h_{s}$ 等) の值をいろいろに変えて $I_{k j}{ }^{11}$ 等の積分 值を計算し式 (16)，(18）の $R_{k j}{ }^{11}, R_{0}{ }^{12}$ 等の值を求め てその結果を図表化しておくという方法を用いることに した。このようにすれば実際にある一定の $n_{g}, n_{s}, h_{g}$, $h_{s}$ 等の值に対してגを求めようとする場合, $\eta, \alpha_{k j}$ 等 は式 (14)，(17) から計算できる既知の定数であるから， 与えられた $n_{g}, n_{s}, h_{g}, h_{s}$ 等の值に忘ずる $R_{k j}{ }^{11}, R_{0}{ }^{12}$ 等の值を図表から読み取って式 (15)，（13）に入れれば $\lambda$ の值は比較的容易に求めることができる。

\section{5. $\boldsymbol{R}_{k j}{ }^{11}$ 等の数值計算}

$R_{k j}{ }^{11}$ 等の值を求めるには $I_{k j}{ }^{11}$ 等の積分を行なわね ばならないが，それには基盤における地震加速度 $\ddot{\phi}(t)$ のパワースペクトル $\Phi(\omega)$ の式の形がわかっていなけ ればならない。本節の計算にはつぎに示す式 ${ }^{2}$ を用いた。

$$
\Phi(\omega)=C_{0} \frac{1+4 h_{0}{ }^{2} \frac{\omega^{2}}{n_{0}{ }^{2}}}{\left(1-\frac{\omega^{2}}{n_{0}{ }^{2}}\right)^{2}+4 h_{0}{ }^{2} \frac{\omega^{2}}{n_{0}{ }^{2}}}
$$

ここに, $C_{0}$ は一定値, $n_{0}$ は地震加速度 スペクトルの 卓越円振動数, $h_{0}$ はスペクトルの山の形に関係する量 である。なお，地震加速度がランダムな波形をもってい ると考えられる場合にはそのパワースペクトルは一定 值となり

$$
\Phi(\omega)=C_{0}
$$

$R_{k j}{ }^{11}$ 等の計算は地盤と橋脚に対していずれも第 2 次 振動までを考えた場合に相当する $P=R=2$ の場合につ いて行なった。また $I_{k j}{ }^{11}$ 等の積分は電子計算機を使用 して留数計算を行ならことによって求めた。なお, $R_{k}{ }^{11}$, $R_{0}{ }^{12}$ 等の計算図表はその一部を後節に示した。

\section{6. 計算例および考察}

著者らは前論において図一1に示した鋼管橋脚の地震 応答を計算し, 地盤の変形を考慮する場合と考慮しない 場合の橋脚天端の最大応答変位の比を地盤の性質をいろ いろ変えた場合について求めた。本節の目的は第 1 に本 論の一適用例を示すこと, 第 2 に本論の統計的計算によ って得られた結果と前論ですでに得られている数值計算

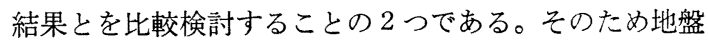
や橋脚の諸元等はすべて前論の場合と同一の数值を用い た。

前論の計算では入力地震波 $\dddot{\phi}(t)$ としてエルセントロ 地震 (May 18，1940） を用いたので, 本論でも式 (23) の $n_{0}$ の值はエルセントロ地震の卓越周期を 0.5 秒前後 と見て $n_{0}=12.56$ を採用した。 $h_{0}$ の值については田治 
見沙にしたがって $h_{0}=0.3$ とした。

前述のごとく地盤変形の影響を明らかにするために， 地盤の性質を前論と同じく表一1 に示すように No. 1 か ら No. 6 まで 6 通りに変えた。いずれの場合にも，地 盤反力係数 $k$ は深さ方向に三角形分布とし, 地盤の厚さ $5.5 \mathrm{~m}$ を 3 等分 $(q=3)$ し, 地盤の せん断弾性係数 $G$ との比 $G / k=20$ とした。なお計算は橋脚の下端が基礎 地盤とヒンジ結合をなしている場合について行なった。

表一1 地盤の性鿓

\begin{tabular}{c|c|c|c|c|c|c}
\hline No. & 1 & 2 & 3 & 4 & 5 & 6 \\
\hline$k_{0}\left(\mathrm{~kg} / \mathrm{cm}^{3}\right)$ & 4.0 & 1.0 & 0.4 & 0.29 & 0.1 & 0.04 \\
$G_{0}\left(\mathrm{~kg} / \mathrm{cm}^{2}\right)$ & 80 & 20 & 8.0 & 5.80 & 2.0 & 0.80 \\
\hline
\end{tabular}

計算結果を図一2 に示す。図一2 は地盤の変形を考え る場合の橋脚天端の変位応答の分散と地盤の変形を考え ない場合のそれとの比の平方根 $\lambda$ (式 (1) からこの值 は橋脚の各最大変位の比に等しい) を $n_{g_{1}} / n_{s 1}$ を横軸に とり，橋脚の減衰定数をパラメータとして表わしたもの である。実線は $h_{s}=0.05$ の場合を, 点線は $h_{s}=0.1$ の 場合を示す。図中の○印と $\times$ 印は前論に示したエルセン トロ地震に対する応答計算結果を示したもので，○印は 同図中の実線に，×印は点線にそれぞれ対応するもので ある。図一2 から前論のエルセントロ地震記録に対して 電子計算機によって刻々求めた応答計算值と本論による 統計的計算值とは比較的よく一致していることがわか る。

図一2振幅の比 $\lambda$

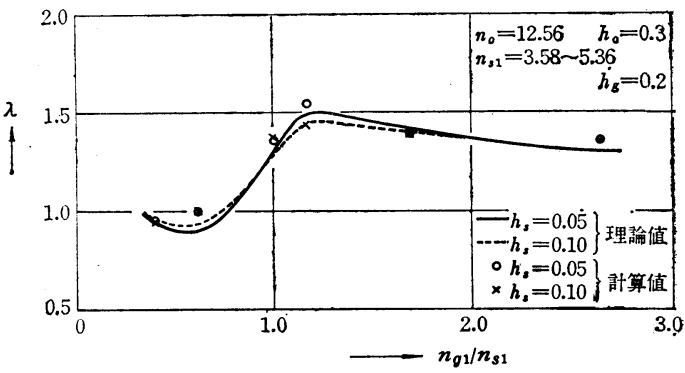

なお，入力地震波に対すう橋脚の刻々 0 位応答を計 算しようとする場合，これ在 modal analysis の手法在 用いて行ならときにどれくらいの掋動次数までとればよ いかの一つの目安として式 (14)，(16)から $\eta_{0} R_{0}{ }^{12}, r^{2} R{ }^{22}$ の值を採用するのも有用な $j$ 法の一一になりうるし考え られる。

\section{7. 基盤での地震動の性䟟の影慗}

式 (18)の $R_{k j}{ }^{11}$ 等の計算には $h_{s}, n_{s} / n_{g}$ の值のみで なく $n_{0}, h_{0}, h_{g}$ 等パラメータの数が多く, したがってい ろいろの入力地震波に対する応答を統計的に計算しよう とする場合にはそのパラメータの值をいろいろに変えて 多くの阐素作らねばならないことになる。しかし $n_{0}$ ， $h_{0}$ の值をそれぞれいろいろ変えて啝脚の応答を統計的 に計算して地盤の変形を考慮する場合の変位応答の分散 と地盤の変形を考慮しない場合のそれとの比の平方根 $\lambda$ をとると,この入の值は $n_{0}, h_{0}$ の值の変化による影響 をわずかしか受けず，上層地盤の性質に応じてほぼ一定 值を有するとみてよいことがわかった。極端な場合とし て，入力地震波として全くランダムな波を考えたとき， すなわち, 入力地震波の特性值 $n_{0}, h_{0}$ を全く無視して $\Phi(\omega)=C_{0}$ とした場合について統計的計算を行なった結 果，入の值の変化はわずかであった。統計的計算がある 現象のいろいろな現われ方に対する一種の平均值的な意 味合いを持つことを考虑すれば $n_{0}, h_{0}$ の変化による 值のわずかの相違は図表の単純化の点からも無視してよ いのではないかと思われる。このように考えてよいとす れば, パラメータの数が少なくなって $h_{s}, h_{g}, n_{s} / n_{g}$ のみ となり入力地震波の性質をほとんど考えることなしに橋 脚の変位応答におよぼす地盤変形の影響を図表を使って 比較的簡単な計算から見積ることができることになる。

\section{8. 応答計算図表}

図一3（1 ，，(2)，（3）は基盤から 入射する地震動を

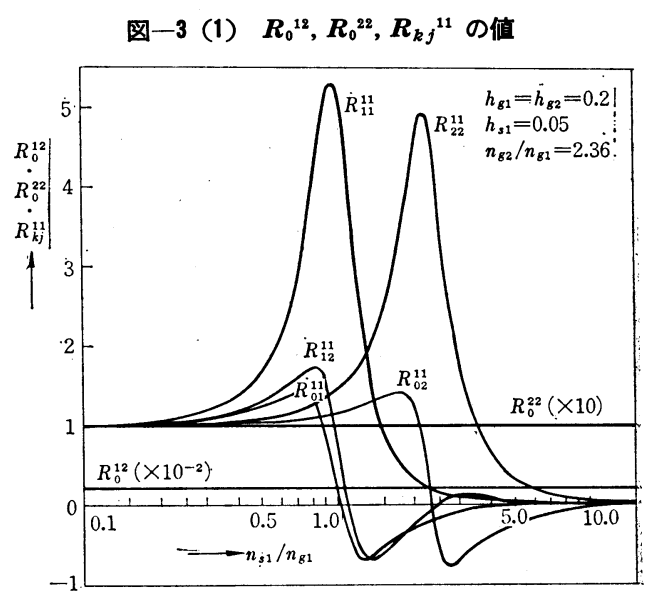

図一3（2） $\boldsymbol{R}_{k j}{ }^{12}$ の 值

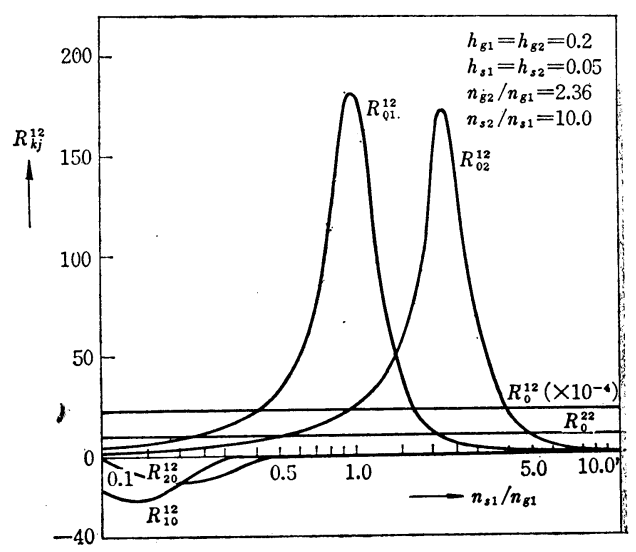




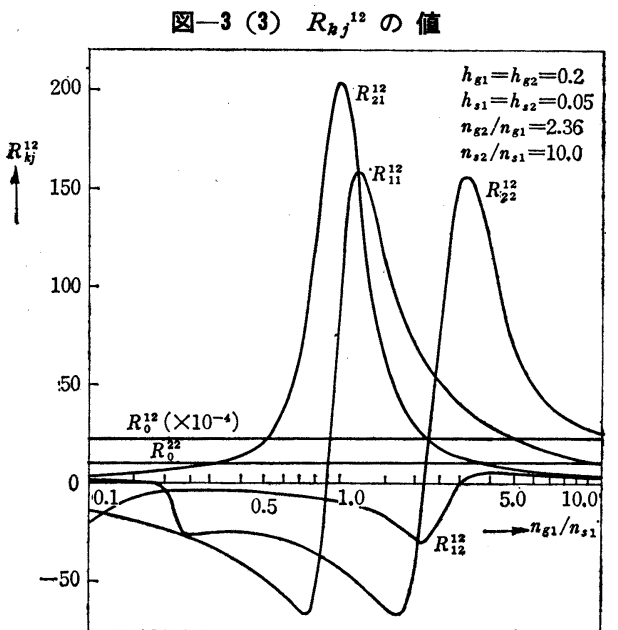

ランダムとして, $h_{s}$ および $h_{g}$ を factor として $n_{s_{1}} / n_{g_{1}}$ の值を横軸にとり， $R_{0}{ }^{k j}, R_{k j}{ }^{11}, R_{k j}{ }^{22}$ の值を図示した ものである。実際の耐震設計においては，この図を用い ることにより地盤変形を考慮する場合の鋼管灀脚の地震
応答の最大値を容易に求めることができる。

9.むす ひ

地盤および鋼管橋脚の振動型と固有振動周期がわかれ ば統計理論より得られた簡単な図表を用いて，地盤変形 を考慮に入れた鋼管橋脚の地震応答を容易に求めうるこ とがわかった。しかし実際問題として水中にある軟弱地 盤の固有振動周期を推定することには相当の困難がある であろう。われわれはこの問題についても目下考察中で ある。

1）小坪清真・高西照彦：「鋼管橋脚の耐震性におよぼす基礎 地盤変形の影響」, 土木学会論文集 148 号, 昭和 42 年 12 月.

2）田治見宏：「耐霞理論 飞関する基礎的研究」, 東大生産技 術研究所報告, Vol. 8, No. 4, 昭和 34 年 3 月.

3) G.W. Housner : Behavior of Structures during Earthquake, Proc. ASCE., Vol. 85, EM 4. Oct. 1959.

(1967.12.25 - 受付) 